\title{
НАПРЯМИ РОЗВИТКУ ПІРИНГОВОГО КРЕДИТУВАННЯ В УКРАЇНІ
}

\section{DIRECTIONS OF PYRING LENDING DEVELOPMENT IN UKRAINE}

\author{
Жаворонок А. В. \\ кандидат економічних наук, доцент \\ доцент кафедри публічних, \\ корпоративних фінансів та фінансового посередництва, \\ Чернівецький національний університет імені Юрія Федьковича, Чернівці \\ ORCID: 0000-0001-9274-8240 \\ Artur Zhavoronok \\ PhD (Economics), Associate Professor, \\ Associate Professor of Department of Public, \\ Corporate Finances and Financial Mediation, \\ Yuriy Fedkovych Chernivtsi National University, Chernivtsi
}

У статті досліджено напрями розвитку пірингового кредитування в Україні. Визначено, що даний вид кредитування тільки-но починає свій розвиток в Україні. В даний час працює тільки дві онлайн платформи пірингового кредитування. Зосереджено увагу на тому, що основною перевагою Р2P кредитування $\epsilon$ доступність, адже зараз кожен має доступ до мережу Інтернет. Визначено основні пропозиції для збільшення темпів розвиткуР2Р кредитування: створення стабільної та зваженої нормативно-правової бази; створення української асоціації онлайн платформ р2р кредитування; створення єдиного сайту, де буде акумульована вся інфоормація про онлайн платформи пірингового кредитування. Наголошено на тому, що слід обов'язково усвідомлювати притаманні перешкоди, перед впровадженням будь-яких нововведень. В будь-якому випадку при створенні чогось нового для платфоорми найбільшою перешкодою стане потреба у виділенні значної суми додаткових коштів. Щоб покращити становище потрібно створити якомога кращі умови для притоку користувачів, які через час принесуть прибуток власникам платформи. Ключові слова: пірингове (P2P) кредитування, банківське кредитування, скоринг, позичальник, онлайн платорорма.

В статье исследованы направления развития пиринговых кредитования в Украине. Определено, что данный вид кредитования только начинает свое развитие в Украине. В настоящее время работает только две онлайн платформы пиринговых кредитования. Сосредоточено внимание на том, что основным преимуществом Р2Р кредитования является доступность, ведь сейчас каждый имеет доступ к Интернет. Определены основные предложения для увеличения темпов розвиткуР2P кредитования: создание стабильной и взвешенной нормативно-правовой базы; создание Украинской ассоциации онлайн платформ p2p кредитования; создание единого сайта, где будет аккумулирована вся информация об онлайн платформы пиринговых кредитования. Отмечено, что следует обязательно осознавать присущи препятствия, перед внедрением любых нововведений. В любом случае при создании чего-то нового для платформы самым большим препятствием станет потребность в выделении значительной суммы дополнительных средств. Чтобы улучшить положение нужно создать как можно лучшие условия для притока пользователей, которые через время принесут прибыль владельцам платформы. Ключевые слова: пиринговое (P2P) кредитование, банковское кредитование, скоринг, заемщик, онлайн платорорма.

The article examines the directions of development of peer lending in Ukraine. It is determined that this type of lending is just beginning its development in Ukraine. Currently, there are only two online peer-to-peer lending platforms. The main advantage of P2P lending is affordability, because now everyone has access to the Internet. The negative side of development is that this type of lending is not regulated by the regulatory framework of Ukraine and has no property security. These features negatively affect the investor and in most cases the investor refuses to invest. To improve the situation, it is necessary to create the best possible conditions for the influx of users, which over time will bring profit to the owners of the platform. The main proposals for increasing the pace of development of P2P lending are identified: the creation of a stable and balanced regulatory framework; creation of the Ukrainian association of online 
p2p lending platforms; creation of a single site where all information about online peer-to-peer lending platforms will be accumulated. According to the results of the study, the following obstacles were identified: lack of awareness of the population and its low financial literacy; non-perception of peer lending by the population; failure of the controlling body to perform its duties; not displaying all credit histories; hacker attacks; unfavorable investment and credit climate in a foreign country; undeveloped demand for peer-to-peer lending in a foreign country; Ukrainian and international financial crises; shortage of solvent borrowers; lack of highly qualified consultants; unqualified and incompetent managers; lack of successful projects; the need for additional time and money; non-relevance and disinterest of the population of the information posted on the site. Be sure to be aware of the inherent barriers before implementing any innovations. In any case, when creating something new for the platform, the biggest obstacle will be the need to allocate a significant amount of additional funds. Therefore, when creating innovations you need to carefully analyze all the pros and cons. Key words: peer-to-peer (P2P) lending, bank lending, scoring, borrower, online platform.

Постановка проблеми. Вітчизняне пірингове (Р2P) кредитування значно відстає від рівня розвитку зарубіжних економічно розвинених країн. Наявний розрив у розвитку проявляється в якості надання послуг, їх диференціації, а також в значному захисті прав кожного з суб'єкта процесу кредитування. Хоча на українському ринку й присутня низка проблем, але на основі зарубіжного досвіду та власних заходів можливо досягти значного зрушення в розвитку онлайн платформ Р2Р кредитування.

Аналіз останніх досліджень і публікацій. Враховуючи інноваційний характер Р2Р кредитування (кредитування між двома фрізичними особами безпосередньо через використання інформаційних технологій) ґрунтовних досліджень особливостей його зародження та надання на сьогодні не існує. Проте, є значна кількість робіт, у яких фрагментарно розглядаються питання щодо організації процесу пірингового кредитування та специфрічні риси, що йому притаманні. До авторів таких праць варто віднести, насамперед, наступних: Заруцька О. П. [1], Прокопенко В.Ю. [2], КузьмукІ.Я. [3], Дубина М.В. [4; 5; 6], Крухмаль О. В. [7], Петренко І. П. [8], Петрушенко Ю. М. [9], Привалова І. М. [10] та інші.

Виділення невирішених раніше частин загальної проблеми, котрим присвячується означена стаття. Незважаючи на наявність ґрунтовних наукових напрацювань з обраної проблематики, питання визначення основих пріоритетних напрямів розвитку пірингового кредитування в Україні зберігають свою актуальність, оскільки даний вид кредитування тільки-но починає свій розвиток в Україні.

Формулювання цілей статті (постановка завдання). Метою даної роботи $є$ визначення основних напрямів розвитку пірингового кредитування в Україні на основі виокремлення основних заходів активізації пірингового кредитування, ідентифрікації та обґрунтування базових перешкод розвитку ринку пірингового кредитування.

Виклад основного матеріалу дослідження. Постійний розвиток банківських операцій та інфрормаційних технологій призвели до розвитку онлайн сервісів кредитування. Формування стабільної та зваженої нормативно-правової бази щодо ринку Р2Р кредитування полягає у створенні урядом законів, що покращать захист прав як інвестора, так і позичальника. Вона повинна забезпечити дієві інструменти та механізми, які можуть використовуватися на практиці, якісно регулюватимуть відносини між різними суб'єктами пірингового кредитування та інше. Доцільно розробити законопроект про діяльність онлайн платфрорм та пірингове кредитування у якому передбачити: контролюючий орган онлайн платформ; порядок створення і державної реєстрації онлайн платформ; порядок регулювання діяльності онлайн платформ; порядок фрормування та використання резерву для відшкодування можливих втрат за кредитними операціями; порядок оформлення Р2P кредитів; порядок повернення боргу позичальником; порядок ведення звітності онлайн платформ; порядок застосування санкцій до онлайн платформ; порядок захисту прав та інтересів кредиторів та позичальників; порядок взаємодії сервісів пірингового кредитування та Фонду гарантування вкладів; порядок оформлення та реалізації заставленого майна; порядок страхування Р2P кредитів; порядок застосування штрафнних санкцій до позичальника у разі невиконання зобов'язань; порядок співпраці з бюро кредитних історій; встановлення контролю за простроченими кредитами; порядок конвертування валют, при виході на зарубіжний ринок; порядок ліквідації онлайн платсрорм.

Уряд повинен передбачити всі можливі варіанти діяльності сервісів Р2Р кредитування та встановити нормативно-правову базу їх регулювання. Без законодавчого регулювання даний вид кредитування, більшість інвесторів вважають, що це фінансова піраміда і не бажають вкладати кошти. Особливо потрібно встановити порядок контролю за неплатоспроможними позичальниками. Адже, через те що позичальник не виплачує вчасно свій борг інвестор не отримує вчасно свої кошти і підривається репутація, онлайн платформи. Така ситуація, звичайно, не сприяє розвитку Р2Р кредитування в Україні. Тому для захисту кредиторів уряд повинен впровадити порядок створення системи скорингу, резервних фондів платформ чи їх співпрацю з Фондом гарантування вкладів.

Важливим моментом $є$ встановлення порядку 
співпраці з бюро кредитних історій. Уряд повинен затвердити обов'язкову співпрацю БКІ та онлайн сервісів, так як це надасть можливість знизити кредитування неплатоспроможних клієнтів. Також, онлайн платформи повинні надавати свою інфрормацію щодо неплатоспроможних клієнтів для мінімізації ризиків неплатежу по кредитах. Такі дії призведуть до підвищення впевненості інвестора про повернення коштів позичальниками. В Україні зареєстровано 10 кредитних бюро, але реально працюють лише чотири.

Щоб збільшити лояльність інвесторів потрібно створити на законодавчому рівні механізм забезпечення позики, що призведе до підвищення бажання надавати кошти платформам. Як наслідок платформи Р2P кредитування збільшать свої темпи розвитку. Забезпеченням позик в основному виступає заставне майно. При створення нормативно-правових актів регулювання пірингового кредитування, потрібно приділити увагу для створення правил оформлення, звернення, стягнення та реалізації застави.

У багатьох випадках заставлене майно оформляється спрощеним способом: скорочене найменування, кількість, ціна. Тому доцільно створити універсальну фрорму описування майна. Проте якщо по формальних розрахунках включити і такі реквізити, як завод - виготовлювач, коди відправника, постачальника, виду операції і т.д., то утвориться громіздка фрорма, користуватися якою буде важко. Тому потрібно використовувати тільки ті параметри, що окремо не настільки повно деталізують предмет застави, але в сукупності з іншими дозволяють його конкретизувати, що дуже важливо в конфоліктній ситуації. До таких параметрів можна віднести: інвентарний заводський номер, найменування майна, що закладається (тип, марка, дата випуску). Треба вказувати початкову вартість [4, с. 99].

Практика показує невідповідність ситуації, в якій опиняється кредитор. Тобто, це положення складається в процесі звернення, стягнення і реалізації закладеного майна. В цьому випадку можна пропонувати наступне - максимальна сума кредиту не повинна перевищувати 10-15\% вартості застави. Справа в тому, що після процедури реалізації майна сума виручки може бути недостатньою для задоволення усіх вимог заставодержателя [5, с. 147].

При укладанні кредитної угоди, кредитор має право вимагати повернути йому кошти, а позичальник зобов'язаний оплачувати платежі в термін. Не дотримання таких домовленостей, між кредитором і позичальником, виникає ризик неповернення коштів. Щоб захистити кредитора від фрінансових збитків, можна скористатись страхуванням. Страхування кредитів - це зменшення або усунення кредитного ризику, який виражається у можливій несплаті позичальником основного боргу і відсотків за ними і є однією з форм забезпечення кредиту. Таким чином, матеріальний прояв ризику кредитної операції полягає в тому, що борг не повертають, а юридично зводиться до невиконання зобов'язань. Тому можна запропонувати страхування від збитків на випадок невиконання вимог як один із принципів вдосконалення управління кредитним портфелем [6, с. 82].

В Україні страхування кредитів можливе у двох варіантах (рис. 1). Саме фінансові збитки виступають об'єктом страхування.

В Україні добровільне страхування ризику не погашення кредитів не набуло значної популярності. Головною причиною $є$ те, що саме фінансова установа сплачує страхові платежі, що в свою чергу впливає на збільшення витрат. Тому установа враховує дані затрати при встановленні ставці відсотка за кредит. Так як збільшується відсоток по кредиту, позичальники не мають бажання звертатися до даної установи.

Другим видом страхування кредитів $є$ добровільне страхування відповідальності позичальника за непогашення кредитів. Фінансові установи сприймають страховий поліс як різновид гарантійного папера страхової компанії банку за фрінансовими зобов'язаннями до його клієнтів позичальників. Цей варіант страхування може забезпечити повернення кредиту і сплати відсотків лише у випадку, коли страхова фрірма згодна і спроможна виплатити страхову винагороду $[7$, c. 94].

Для контролю та регулювання діяльності онлайн сервісів, потрібно визначити контролюючий орган (Далі - Орган). Він повинен взаємодіяти з усіма платформами Р2Р кредитування, не перешкоджаючи їх розвитку і за необхідності надавати певні регулюючі розпорядження. Наприклад, у разі ліквідації платорорми Орган повинен проконтролювати, щоб усі позичальники без винятку повернули борг з відсотками кредитору. Орган повинен встановлювати правила і вимагати від онлайн сервісів справність веб-сайтів, цілком прозорі умови співпраці, професійність і чесність у діяльності.

Органу потрібно постійно надавати розпорядження про проведення платформами контролю і нагляду за справністю роботи веб-сайтів. В даний час швидко розвивається онлайн простір, а разом з цим розвиваються «шкідники» Інтернету. Хакери можуть зламати сайт і отримати несанкціонований доступ до фрайлів сайту. Це проблема катастрофрічного розміру. Як наслідок гроші не потраплять до інвесторів чи позичальників, а вся звітність буде стерта. У такому випадку репутація сервісів пірингового кредитування буде підірвана. Тому потрібно постійно оновлювати сайт. Перед оновленням слід зробити резервну копію та оновлюватися 


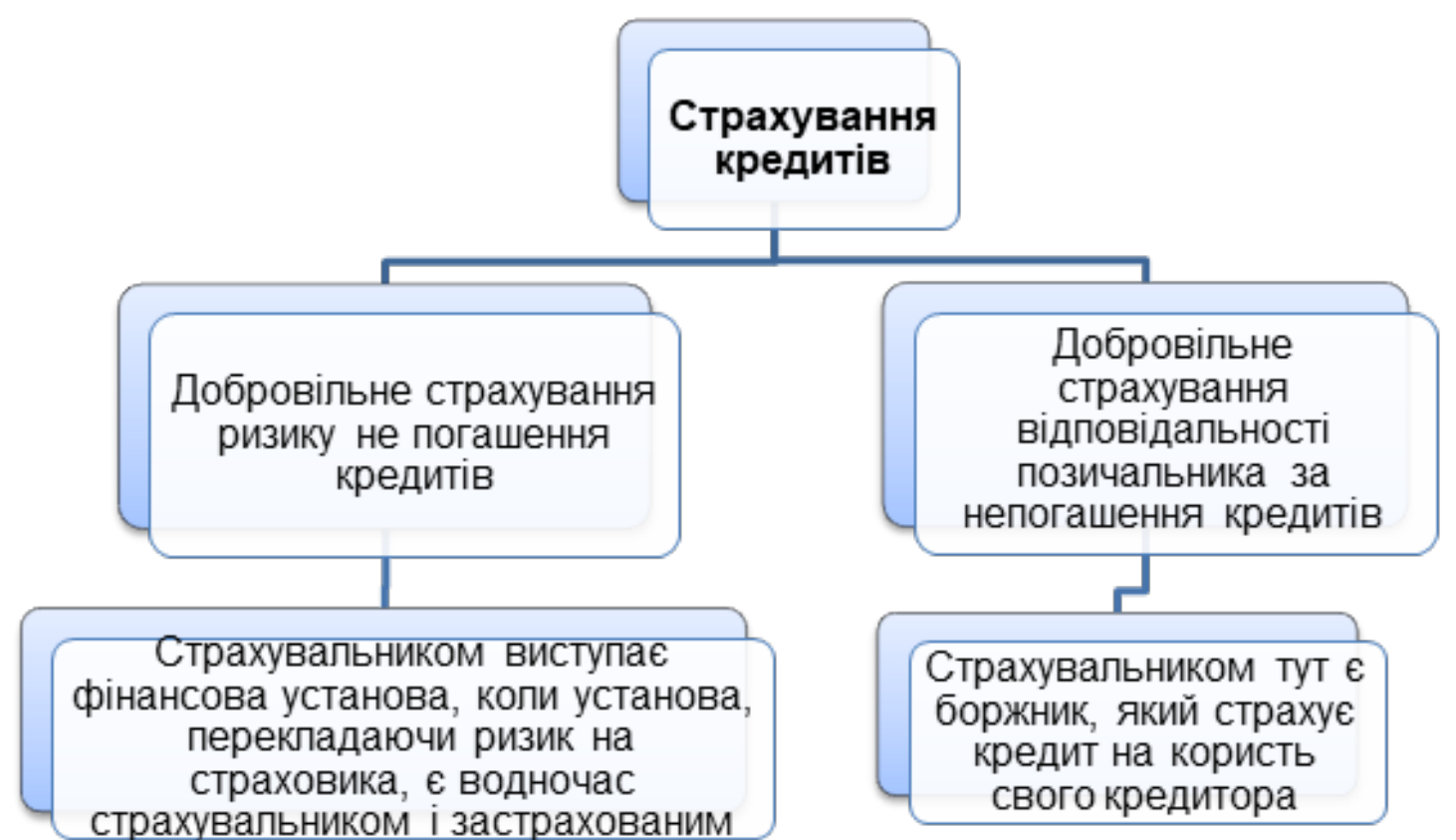

Рис. 1. Види страхування кредитів

Джерело: складено автором на основі [5, с. 148]

варто поступово, крок за кроком, а не все відразу. Варто заздалегідь сповістити користувачів про оновлення і зробити перевірку сайту після оновлення. Потрібно постійно контролювати відгуки користувачів платформи, щоб вчасно відреагувати на неполадки. Налагоджена робота онлайн платорорм надасть можливість якісного і швидкого обслуговування клієнтів.

Можливим є створення Української асоціації онлайн платформ пірингового кредитування. Метою її діяльності $є$ задоволення та захист прав та інтересів ії членів. Діяльність асоціації повинна бути спрямована на популяризацію пірингового кредитування та становлення даного виду кредитування в суспільстві. Вона повинна слідкувати за діяльністю всіх учасників та вчасно надавати регулюючі вказівки. Також, асоціація може підготовлювати проекти нормативних актів, щодо регулювання непередбачених раніше ситуацій. Асоціація повинна займатися розвитком та зміцненням зв'язків із зарубіжними об'єднаннями, а також сприяти активній діяльності всіх своїх членів у міжнародній діяльності.

Для створення зв'язків із зарубіжними об'єднаннями потрібно асоціації виокремити декілька бажаних країн, а з них вибрати найбільш перспективні взаємовідносини. Також, онлайн сервіси, що $€$ учасниками асоціації можуть надавати свої послуги закордонним користувачам. Для цього потрібно створити такі умови кредитування, які будуть конкурентними для кредитної системи зарубіжної країни. Для їх розповсюдження потрібно користуватися різного роду рекламою, наприклад в соціальних мережах, листівки, банери, смс-розсилання.

Для забезпечення захисту прав інвесторів, можливим $є$ створення загального резервного фонду асоціації. Для цього асоціація повинна встановити суму коштів, яку повинен внести кожен ії учасник. У випадку виникнення непередбаченої ситуації з онлайн платформою, коштами цього резерву будуть покриті збитки учасників кредитних відносин.

Для покращення сприйняття сервісів Р2P кредитування можливе створення загального кол-центру Української асоціації онлайн платорорм пірингового кредитування. Він надасть можливість спілкування з клієнтами, тобто консультування та отримання пропозицій чи зауважень по роботі сервісів кредитування. Можна створити не великий кол-центр, який з розвитком асоціації буде збільшуватись по мірі необхідності. Цей кол-центр, для більшої ефрективності обробки дзвінків, складався б з двох рівнів (рис. 2).

На першому рівні, оператори надають основну інфрормацію про Р2Р кредитування та роботу платформи. Якщо людині, яка телефонує, потрібна додаткова інформація, то дзвінок перенаправляється до операторів другого рівня. Вони повинні відповісти на всі специфічні питання. Працівники кол-центру повинні бути обізнані у піринговому кредитуванні та акцентувати увагу на роз'ясненні найбільш значимих аспектів кредитної угоди. Створення компетентного кол-центру допоможе сервісам P2P кредитування розповсюджувати правильну інфрормацію щодо роботи платформ. Тому що більшість людей можливо хочуть взяти кредит на онлайн платформі чи інвестувати кошти в неї, але їх стримує незнання її роботи.

На першому рівні, оператори надають основну інформацію про Р2Р кредитування та роботу платформи. Якщо людині, яка телефонує, потрібна 


\begin{tabular}{|c|c|}
\hline Перший рівень & $\begin{array}{l}\text { - Надання загальної інформації про Р2P } \\
\text { кредитування }\end{array}$ \\
\hline Другий рівень & $\begin{array}{l}\text { - Надання більш компетентної консультації } \\
\text { у складних питаннях }\end{array}$ \\
\hline
\end{tabular}

Рис. 2. Схема кол-центру онлайн платформи

Джерело: складено автором

додаткова інформація, то дзвінок перенаправляється до операторів другого рівня. Вони повинні відповісти на всі специфічні питання. Працівники кол-центру повинні бути обізнані у піринговому кредитуванні та акцентувати увагу на роз'ясненні найбільш значимих аспектів кредитної угоди. Створення компетентного кол-центру допоможе сервісам P2P кредитування розповсюджувати правильну інформацію щодо роботи платформ. Тому що більшість людей можливо хочуть взяти кредит на онлайн платформі чи інвестувати кошти в неї, але їх стримує незнання її роботи.

Можливе створення персональних менеджерів для клієнтів. Менеджера будуть взаємодіяти з найбільш частими клієнтами онлайн сервісу, а також будуть вирішувати складні вузькоспеці- альні питання. Отже, при створенні менеджерів з роботою клієнтів потрібно створити і стандарти обслуговування.

Політика становлення і розвитку асоціації повинна бути спрямована на постійний розвиток іiї членів. Тобто, учасникам асоціації потрібно постійно удосконалювати існуючі і впроваджувати нові технології обслуговування клієнтів. Наприклад, якщо клієнт реєструється з мобільного телефону то можливо запропонувати не вручну вводити дані банківської картки, а відсканувати через камеру мобільного телесону. Дуже зручний спосіб, хоча іноді можливі помилки тому потрібно обов'язково перевіряти дані (рис. 3).

Для розвитку асоціації повинні розвиватись ії учасника, тобто онлайн платформа. Найбіль-

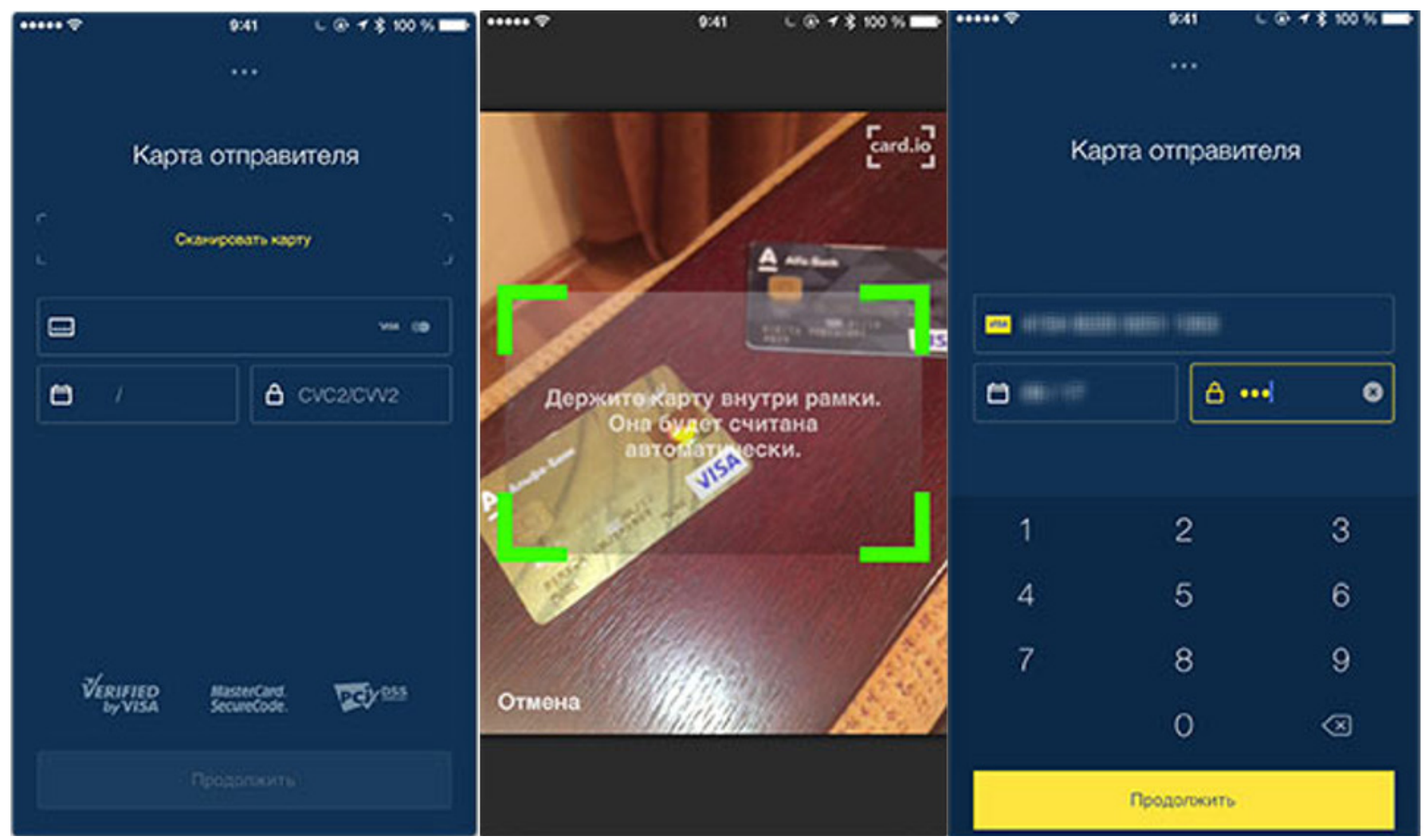

Рис. 3. Приклад сканування банківської картки

Джерело: складено автором

шого розвитку онлайн сервіси отримують коли збільшують свою клієнтську базу. Для залучення нових клієнтів платформам потрібно постійно оновлювати кредитні та інвестиційні пропозиції. Наприклад, створити програму з кредитування підприємців, які бажають створити власну спра- ву, тобто кредитувати стартовий капітал. Банки не мають великого бажання надавати такі кредити. Українські банки не впевнені, що бізнес буде розвиватися, а позичальник зможе повернути кошти вчасно. Тому не охоче приймає на себе такий ризик. Тому Р2P кредитування $є$ виходом 
з такої ситуації, адже платформа не приймає на себе жодних ризиків. В цілому при активній роботі даного проекту збільшиться не тільки темп зростання Р2Р кредитування, а й загалом економічний розвиток в Україні. Отже, власники онлайн сервісу повинні постійно створювати стимули для залучення нових клієнтів, вигадувати щось нове.

Якщо платорорма пірингового кредитування запровадить новий напрямок кредитування, то потрібно розповсюдити дану інформацію серед населення. Тому час від часу потрібно проводити рекламні акції та презентації. Головною метою презентацій має бути вірне і точне донесення інформації.

Залучення клієнтів, також можливе шляхом надання пільг платформою певним верствам населення. Найбільший ефект від нового кредитного продукту досягатиметься через додаткові переваги для суб'єкта господарювання - пільги. Більший інтерес для суб'єктів господарювання має саме набір супутніх послуг і переваг, які забезпечують кредиту неповторність і цільовий характер, що відрізнятиме його від кредитів, наданих на загальних умовах. Надання певних пільг стимулюватиме зацікавленість суб'єктів господарювання до кредитів, зробивши їх доступнішими. Це сприятиме підвищенню ефективності кредитних взаємин як суб'єктів господарювання, так і сервісів пірингового кредитування [5, с. 147].

Також, можливе створення єдиного сайту, де акумульована вся інформація про онлайн платформи пірингового кредитування. У ньому буде міститись детальна інформація про діючі платформи, а саме: умови кредитування; умови інвестування коштів; необхідний перелік документів для реєстрації у платформі; перелік нормативно-правових актів, що регулюють діяльність платформ; звітність онлайн платформ; аукціонні пропозиції платформ; відгуки та коментарі користувачів платформ.

Даний сайт буде дуже зручним для користувачів, адже буде акумульована вся потрібна, без зайвого нагромадження, інформація. На цьому сайті можна буде наглядно відстежити всі умови по кредитуванню та інвестуванню коштів і виокремити найбільш вигідні умови. Сайт допоможе швидше підібрати потрібну онлайн платформу без зайвого витрачання часу.

Отже, перераховані заходи можуть позитивно вплинути на підвищення темпів зростання Р2Р кредитування в Україні та дозволять гідно конкурувати на ринку кредитних послуг в складних економічних умовах. В результаті створення дієвої та стабільної нормативно-правової бази з'явиться можливість вивести на новий рівень розвитку пірингове кредитування. Так як користувачі будуть впевнені, у тому що даний вид кредитування є надійним та безпечним для вкладання коштів.
Створення асоціації дозволить українським платформам отримати підтримку у розвитку, а саме сворення резервного фонду, кол-центру та виходу на зарубіжні ринки. Веб-сайт з акумульованою інформацією, надасть можливість користувачам мінімізувати свій час у пошуках найвигідніших кредитних чи інвестиційних умов.

Основною перешкодою, яка постає перед онлайн платформою пірингового кредитування $€$ ризик. Взагалі ризик є невід'ємним елементом у кредитній системі країни. Потрібно завжди прораховувати всі можливі варіанти розвитку онлайн сервісу і надавати найбільшу увагу перешкодам. Недостатня увага може призвести до поганих наслідків та звести всю роботу платформи нанівець. Тому потрібно завжди слідкувати за перешкодами діяльності та робити все можливе, щоб їх мінімізувати.

Уряд витрачає значний проміжок часу, при створенні стабільної та зваженої нормативноправової бази. Але ці витрати часу можуть бути марними, так як населення не сприйме цей вид кредитування. В даний час напрямок пірингового кредитування в Україні новий і не набув значної популярності. Як аналізувалося у другому розділі, в Україні в даний час нормально діє тільки дві платформи, хоча і вони не вражають своїми показниками в порівнянні із зарубіжними онлайн сервісами. Я впевнена, що більшість людей взагалі ніколи не чули про даний вид кредитування.

Також, може виникнути складність у регулюванні діяльності контролюючого Органу. Як і більшість організацій, він може загрузнути в корупції. Це у свою чергу призведе до часткового або взагалі не виконання обов'язків Органом. Онлайн платформи пірингового кредитування не будуть належним чином регулюватися та контролюватися. що негативним чином відіб'ється на розвитку пірингового кредитування.

Перешкода $є$ і відносинах онлайн платформ та бюро кредитних історій. Справа в тому, що не всі кредитні історій направляються до БКІ. Більшість кредитних організацій надають відомості про позичальників за їх згоди. Тому більшість інформації може не відображаються у даних бюро. Що в свою чергу негативно вплине на становлення онлайн платформ, адже вони не будуть попереджені про неплатоспроможність позичальника. Тобто, недостатній розвиток бюро кредитних історій призводить до ускладнення оцінки ризиків та можливостей позичальників.

При встановленні урядом обов'язкового механізму забезпечення позики, може виникнути ризик ліквідності застави. В даний час в Україні складне як політичне, так і економічне становище. Тому протягом дії кредитного договору може виникнути ризик знецінення предмету застави. Також на основі постійних криз виникає несприятливий 
інвестиційний та кредитний клімат в державі, що також виступає перешкодою в розвитку Р2P кредитування.

Дана форма отримання кредиту пов'язана з наданням в мережу Інтернет великої кількості особистих даних. Загальновідомо, що безпека особистих даних є однією з найбільш гострих проблем у глобальній мережі, і протидіяти хакерам часто дуже складно. Саме ця обставина часто зупиняє велику кількість людей, які замислювалися про взяття кредиту в онлайн-режимі. Тому значна кількість користувачів відмовляється від отримання кредиту онлайн, щоб не зазнати ризику шахрайського використання даних. Тому власники сервісу онлайн кредитування повинні постійно вдосконалювати контроль і нагляд за справністю роботи онлайн платформи. Також, створювати всі умови для захисту особистих даних користувачів.

Звичайно асоціація та її учасники не повинні стояти на місці, а постійно розвиватися, виходячи на зарубіжні ринки кредитування. Але при цьому виникають перешкоди. По-перше це міжнародні фінансові кризи, тому можна зазнати збитку, не отримавши жодної вигоди. По-друге, нерозвинений попит на онлайн кредитування та додаткові витрати у рекламуванні сервісів пірингового кредитування. По-третє, це виникнення несприятливого інвестиційного клімату в зарубіжній країні, що знову зведе нанівець всі старання. По-четверте, дефіцит платоспроможних позичальників, що значно підірве довіру інвесторів до платформ Р2Р кредитування.

Створення резервного фонду для учасників асоціації призведе до додаткових витрат. Що негативно буде сприйнято онлайн сервісами. Отже, платформи підіймуть відсоткові ставки за обслуговування, щоб не зменшуючи свого прибутку сплачувати внески до резервного фонду. Такі дії бурять позичальників і платформи можуть зазнати ризик відтоку клієнтів.

Як згадувалося вище, для розвитку асоціації P2Р кредитування в Україні можна створити колцентр та персональних менеджерів для клієнтів. Що буде гарним поштовхом для збільшення довіри населення до онлайн сервісів. Але як і у всіх нововведеннях існують перешкоди. На платформу ляже відповідальність підібрати і навчити людей, які будуть кваліфікованими та компетентними у наданні консультацій та вирішенні складних питань. Засновники сервісу повинні надати значних зусиль щоб ця система працювала. Але працювала вигідно для компанії. Тому потрібно запровадити контроль за якісним консультуванням. Це всі дії потребують затрати не тільки часу, а й значних додаткових коштів. При виникненні додаткових затрат, власними сервісу можуть підняти відсотки по кредитах, що негативно сприйметься користувачами.
Платформи, що є учасниками асоціації та і взагалі всі онлайн сервіси повинні для збільшення клієнтської бази:

- оновлювати кредитні та інвестиційні пропозиції;

- удосконалювати існуючі і впроваджувати нові технології для якісного і швидкого обслуговування клієнтів.

Власники платформ не завжди можуть запровадити саме той кредитний продукт, який очікують кредитори та позичальники. Ризик невдалих проектів може понести за собою невиправдані витрати часу та коштів. Тому потрібно отримувати зворотній зв'язок від користувачів, щоб дізнатися що сам необхідно впровадити. Також, користувачі можуть не користуватись даними технологіями і власники платформи зазнають витрат. I знову ж стикаємось з ризиком невиправданих витрат часу та коштів.

Надання пільг певним верствам населення, також несе значні перешкоди в розвитку не тільки платформ асоціації, а й ризики для кредиторів. Якщо пільга буде стосуватись зменшенню відсотка по кредиту, то платформа і позичальник отримають менший дохід. Такі обставини негативно будуть впливати на становище як платформи так і позичальника. Якщо пільга буде стосуватись пом'якшенню критеріїв отримання кредиту, то дане рішення негативно вплине на кредиторів. Вони можуть не захотіти вкладати в такі проекти власні кошти. При пом'якшенні умов отримання кредиту на кредитора лягають ризики не погашення суми основного боргу та несплати процентів по кредиту, тобто ризик неплатоспроможності позичальника. Взагалі кредитування є досить ризикованою діяльністю, оскільки наявний ризик неповерненості позики, що в свою чергу вже виключає отримання прибутку від даної операції.

Ще більше затрат може понести платформа при розповсюдженні реклами. Якщо власники платформи приймають рішення про поширення інформації, то потрібно відповідально віднестись до цього завдання. Потрібно визначити цільову аудиторію, знайти шляхи розповсюдження реклами, прорахувати можливий дохід і найголовніше визначити в яку суму обійдеться даний процес. Необхідно виділити основні напрямки розповсюдження та виокремити з них найбільш вигідні. Ризиком при запуску рекламної компанії може бути не сприйняття населенням інформації. Тому при не вдалій рекламі виникає ризик не покриття затрат, направлених на здійснення заходів.

При створенні єдиного сайту, де буде акумульована інформація про Р2Р кредитування в Україні можливе виникнення хвилі обурення власників платформ. Це буде спричинене не бажанням власників висвітлення інформації на інших сайтах. Така реакція можлива через додатковий кон- 
троль цього веб-сайту на правдивість інформації. Взагалі населення може не сприйняти цей сайт і не користуватись ним.

Зважаючи на існуючі тенденції, що склалися на кредитному ринку України, слід обов'язково усвідомлювати притаманні перешкоди, перед впровадженням будь-яких нововведень. В будь-якому випадку при створення чогось нового для платформи найбільшою перешкодою стане потреба у виділенні значної суми додаткових коштів. Тому при створенні нововведень потрібно уважно проаналізувати всі за і проти.

Висновки 3 цього дослідження і перспективи подальших розвідок у даному напрямку. Для початку потрібно встановити регулювання та контроль онлайн сервісів на законодавчому рівні. Формування стабільної та зваженої нормативноправової бази щодо ринку Р2Р кредитування полягає у створенні урядом законів, що покращать захист прав як інвестора, так і позичальника. Без законодавчого регулювання даний вид кредитування, більшість інвесторів вважають, що це фрінансова піраміда і не бажають вкладати кошти. Уряд повинен затвердити обов'язкову співпрацю БКІ та онлайн сервісів, так як це надасть можливість знизити кредитування неплатоспроможних клієнтів. Щоб збільшити лояльність інвесторів потрібно створити на законодавчому рівні механізм забезпечення позики, що призведе до під- вищення бажання надавати кошти платформам. Для контролю та регулювання діяльності онлайн сервісів, потрібно визначити контролюючий орган. Він повинен взаємодіяти з усіма платорормами P2P кредитування, не перешкоджаючи їх розвитку і за необхідності надавати певні регулюючі розпорядження. Можливим $є$ створення Української асоціації онлайн платформ пірингового кредитування. Для покращення сприйняття сервісів Р2P кредитування можливе створення загального кол-центру Української асоціації онлайн платфрорм пірингового кредитування. Він надасть можливість спілкування з клієнтами, тобто консультування та отримання пропозицій чи зауважень по роботі сервісів кредитування. Отже, перераховані заходи можуть позитивно вплинути на підвищення темпів зростання Р2Р кредитування в Україні та дозволять гідно конкурувати на ринку кредитних послуг в складних економічних умовах. Основною перешкодою, яка постає перед онлайн платформою пірингового кредитування $є$ ризик. Слід обов'язково усвідомлювати притаманні перешкоди, перед впровадженням будь-яких нововведень. В будь-якому випадку при створення чогось нового для платформи найбільшою перешкодою стане потреба у виділенні значної суми додаткових коштів. Тому при створенні нововведень потрібно уважно проаналізувати всі за і проти.

\section{БІБЛІОГРАФІЧНИЙ СПИСОК:}

1. Заруцька О. П., Синюк А. О. Міжнародний досвід та вітчизняна практика розвитку платформ Р2Р-кредитування: проблеми та перспективи. Вісник Дніпропетровського університету. Серія : Економіка. 2017. T. 25, вип. 11(1). C. 118-123. URL: http://nbuv.gov.ua/UJRN/vdumov 2017 25_11\%281\%29_20 (дата звернення: 07.07.2021).

2. Прокопенко В. Ю., Дубина М. В. Кредитна інфрраструктура: особливості визначення сутності категорії. Науковий вісник Ужгородського університету. Серія „,Економіка”. 2015. Випуск 1 (45). Том 1. С. $209-212$.

3. Кузьмук І. Я., Губатюк І. В. Зарубіжний досвід формування регуляторного механізму Р2P кредитування. 2018. URL: http://www.visnyk-econom.uzhnu.uz.ua/archive/19_2_2018ua/15.pdf (дата звернення: 07.07.2021).

4. Dubyna M., Zhavoronok A., Kudlaieva N. \& Lopashchuk I. Transformation of Household Credit Behavior in the Conditions of Digitalization of the Financial Services Market. Journal of Optimization in Industrial Engineering. 2021. 14(1). P. 97-102. DOI: https://doi.org/10.22094/JOIE.2020.677835

5. Дубина М. В., Жаворонок А. В., Савчук Д. Г. Світовий досвід розвитку пірингового (Р2Р) кредитування. Причорноморські економічні студії. 2019. Вип. 45. C. 145-151. DOI: http://doi.org/10.32843/bses.45-27

6. Дубина М. В., Шишкіна О. В. Сутність та система інфраструктури кредитного ринку України. Наукові записи Інститут законодавства Верховної ради України. 2017. № 4. С. 80-86.

7. Крухмаль О. В., Заєць О. С. Peer-to-peer кредитування в Україні: перспективи розвитку та виклики для банків. Міжнародний науковий журнал «/нтернаука». 2017. № 2(2). C. 93-96. URL: http://nbuv.gov.ua/UJRN/ mnj $2017 \quad 2 \% 282 \% 29 \quad 21$ (дата звернення: 07.07.2021).

8. Петренко I. П. Р2P кредитування як новітній метод фінансування інвестиційних поектів. URL: https:// www.sworld.com.ua/index.php/ru/economy-315/financial-cash-flow-and-credit-315/26314-315-125 （дата звернення: 07.07.2021).

9. Петрушенко Ю. М. Новітні підходи до фрінансування розвитку місцевих громад: від реконізму до Р2Р-кредитування. Вісник Української академії банківської справи. 2014. № 1. С. 90-94. URL: http://nbuv.gov.ua/UJRN/ VUABS_2014_1_20 (дата звернення: 07.07.2021).

10. Привалова І. М. Р2Р кредитування - як елемент конкуренції на ринку банківських послуг України. Регіональна бізнес-економіка та управління. 2014. № 2. С. 84-88. 


\section{REFERENCES:}

1. Zarutska, O. P., Syniuk, A. O. (2017). Mizhnarodnyi dosvid ta vitchyzniana praktyka rozvytku platform R2R-kredytuvannia: problemy ta perspektyvy [International experience and domestic practice develop the R2Rlending platform: problems and prospects]. Visnyk Dnipropetrovskoho universytetu. Seriia : Ekonomika - Bulletin of Dnipropetrovsk University. Series: Economics. 25. 11(1). Pp. 118-123. Access mode: http://www.visnyk-econom. uzhnu.uz.ua/archive/19_2_2018ua/15.pdf (accessed 07 July 2021). [in Ukrainian].

2. Prokopenko, V. Yu., Dubyna M. V. (2015). Kredytna infrastruktura: osoblyvosti vyznachennia sutnosti katehorii [Credit infrastructure: especially available category categories]. Naukovyi visnyk Uzhhorodskoho universytetu. Seriia „Ekonomika” - Uzhgorod University Scientific Bulletin. Economy series. 1 (45). Tom 1. Pp. 209-212. [in Ukrainian].

3. Kuzmuk, I. Ya., Hubatiuk, I. V. (2018). Zarubizhnyi dosvid formuvannia rehuliatornoho mekhanizmu R2R kredytuvannia [Foreign experience in the formation of the regulatory mechanism of P2P lending] - Polluted realized regulatory business R2R lending. Access mode: http://www.visnyk-econom.uzhnu.uz.ua/archive/19_2_2018ua/15. pdf (accessed 07 July 2021). [in Ukrainian].

4. Dubyna, M., Zhavoronok, A., Kudlaieva, N. \& Lopashchuk, I. (2021). Transformation of Household Credit Behavior in the Conditions of Digitalization of the Financial Services Market. Journal of Optimization in Industrial Engineering. 14(1). Pp. 97-102. DOI: https://doi.org/10.22094/JOIE.2020.677835

5. Dubyna, M., Zhavoronok, A., Savchuk, D. (2019). Svitovyy dosvid pozvytku piryngovogo (P2P) kredytuvannya [Worldwide Peer-To-Peer (P2p) Lending Experience]. Prychornomorski ekonomachni studii. Vol. 45. Pp. 145-151. DOI: http://doi.org/10.32843/bses.45-27 [in Ukrainian].

6. Dubyna, M. V., Shyshkina, O. V. (2017). Sutnist ta systema infrastruktury kredytnoho rynku Ukrainy [The social and credit infrastructure market of Ukraine]. Naukovi zapysy Instytut zakonodavstva Verkhovnoi rady Ukrainy - Institute of Law The Verkhovna Rada of Ukraine. 4. Pp. 80-86. [in Ukrainian].

7. Krukhmal, O. V., Zaiets, O. S. (2017). Peer-to-peer kredytuvannia v Ukraini: perspektyvy rozvytku ta vyklyky dlia bankiv [Peer-to-peer lending in Ukraine: prospects for development and choice for citizens]. Mizhnarodnyi naukovyi zhurnal „Internauka” - International scientific journal „Internship”. 2(2). Pp. 93-96. Access mode: http://nbuv.gov.ua/ UJRN/mnj_2017_2\%282\%29_21 (accessed 07 July 2021). [in Ukrainian].

8. Petrenko, I. P. P2P kredytuvannia yak novitnii metod finansuvannia investytsiinykh poektiv [P2P lending as a new method of financing various projects]. Access mode: https://www.sworld.com.ua/index.php/ru/economy-315/ financial-cash-flow-and-credit-315/26314-315-125 (accessed 07 July 2021). [in Ukrainian].

9. Petrushenko, Yu. M. (2014). Novitni pidkhody do finansuvannia rozvytku mistsevykh hromad: vid rekonizmu do P2P-kredytuvannia [New approaches to the international development of local people: from reconism to P2P lending]. Visnyk Ukrainskoi akademii bankivskoi spravy - Bulletin of the Ukrainian Academy of Military Affairs. 1. Pp. 90-94. Access mode: http://nbuv.gov.ua/UJRN/VUABS_2014_1_20 (accessed 07 July 2021). [in Ukrainian].

10. Pryvalova, I. M. (2014). R2R kredytuvannia - iak element konkurentsii na rynku bankivskykh posluh Ukrainy [P2R Lending - Product Competitiveness in the Business Services Market of Ukraine]. Rehionalna biznes-ekonomika ta upravlinnia - Regional Business Economics and Management. 2. Pp. 84-88. [in Ukrainian]. 